\title{
Investigation of the Presence of Francisella tularensis and Acanthamoeba spp. in the Drinking Water of Sivas Province, Turkey
}

\section{Sivas İli İçme Sularında Francisella tularensis ve Acanthamoeba spp. Varlıg̃ının Araștırılması}

Mehmet ATAȘ'(ID), Ömer POYRAZ²(ID)

\footnotetext{
${ }^{1}$ Department of Pharmaceutical Microbiology, Faculty of Pharmacy, Sivas Cumhuriyet University, 58140, Sivas, Turkey

2 Department of Medical Microbiology, Faculty of Medicine, Sivas Cumhuriyet University, 58140, Sivas, Turkey
}

Cite this article as: Ataş $M$, Poyraz Ö. Investigation of the presence of Francisella tularensis and Acanthamoeba spp. in the drinking water of Sivas province, Turkey. FLORA 2021;26(1):163-71.

\begin{abstract}
Introduction: Tularaemia is a zoonotic disease caused by Francisella tularensis. F. tularensis subsp. holarctica is primarily isolated in Northern Europe, the Balkans, Turkey, Siberia, and the Far East, and it is mostly responsible for waterborne outbreaks. F. tularensis, which is a facultative intracellular bacterium, may survive inside Acanthamoeba castellani, which is a free-living amoeba in water resources; this symbiotic life allows the bacteria to survive in water and mud for months. In this study, drinking water samples taken during the tularaemia outbreak and non-outbreak regions were compared in terms of the presence of Francisella tularensis and Acanthamoeba spp., and the role of Acanthamoeba was investigated in tularemia outbreaks observed in Turkey.
\end{abstract}

Materials and Methods: This study was conducted in the province of Sivas located in the central Anatolia region in Turkey, and a total of 300 water samples were used. Glucose-cysteine-blood agar (GCBA) and non-nutrient agar (NNA) were used for the isolation of F. tularensis and Acanthamoeba, respectively. Each isolate was identified by PCR technique.

Results: A total of 30 (10\%) F. tularensis and 28 (9.33\%) Acanthamoeba spp. isolates were produced by culture method. All bacterial strains were confirmed with $P C R$ as to be F. tularensis subsp. holarctica. In our study, concurrent presence of F. tularensis and Acanthamoeba were detected in two water samples. There were no statistically significant differences between the water samples taken from outbreak and non-outbreak regions in terms of the presence of Acanthamoeba $(p>0.05)$.

Conclusion: Even though experimental studies have shown that F. tularensis may survive inside Acanthamoeba spp. and its viability continues, our study could not identify a relationship between tularemia outbreak and Acanthamoeba spp. New research on this issue may have a contribution on tularemia epidemiology.

Key Words: Francisella tularensis; Acanthamoeba; Tularemia; Tap water; PCR 
ÖZ

\title{
Sivas ili İçme Sularında Francisella tularensis ve Acanthamoeba spp. Varlıg̃ının Araștırılması
}

\author{
Mehmet ATAȘ', Ömer POYRAZ²
}

\footnotetext{
${ }^{1}$ Sivas Cumhuriyet Üniversitesi Eczacılık Fakültesi, Farmasötik Mikrobiyoloji Anabilim Dalı, Sivas, Türkiye

2 Sivas Cumhuriyet Üniversitesi Tıp Fakültesi, Tıbbi Mikrobiyoloji Anabilim Dalı, Sivas, Türkiye
}

\begin{abstract}
Giriş: Tularemi Francisella tularensis tarafından oluşturulan zoonotik bir hastalıktır. Çoğunlukla su kaynaklı salgınlardan sorumlu olan F. tularensis subsp. holarctica, başlıca Kuzey Avrupa, Balkanlar, Türkiye, Sibirya, Uzak Doğu'dan izole edilmektedir. Fakültatif bir hücre içi bakteri olan F. tularensis, su kaynaklarında serbest yaşayan bir amip olan Acanthamoeba castellani içinde yaşayabilir; bu simbiyotik yaşam, bakterilerin aylarca suda ve çamurda hayatta kalmalarını sağlamaktadır. Bu çalışmada tularemi salgını bölgelerinden ve salgın dışı bölgelerden alınan içme suyu, Francisella tularensis ve Acanthamoeba spp. varlığı açısından karşılaştııılmış ve Acanthamoeba'nın Türkiye'de gözlenen tularemi salgınlarındaki rolü araştırılmıştır.
\end{abstract}

Materyal ve Metod: Bu çalıșma, Türkiye'de iç Anadolu bölgesindeki Sivas ilinde gerçekleştirildi ve toplam 300 su örneği kullanıldı. F. tularensis ve Acanthamoeba izolasyonu için sırasıyla glukozlu sisteinli kanlı agar (GSKA) ve besleyici değeri olmayan agar (BDA) kullanıldı. Her izolat $P C R$ yöntemi ile tiplendirildi.

Bulgular: Toplamda kültür yöntemi ile 30 (\%10) F. tularensis ve 28 (\%9.33) Acanthamoeba spp. izolatı üretildi. Tüm bakteriyel kökenlerin F. tularensis subsp. holarctica olduğu PCR ile doğrulandı. Çalışmamızda iki su örneğinde F. tularensis ve Acanthamoeba'nın aynı anda bulunduğu tespit edildi. Salgın görülen ve salgın görülmeyen bölgelerden alınan su örneklerinde Acanthamoeba varlı̆ı açısından istatistiksel olarak anlamlı fark saptanmadı ( $p>0.05$ ).

Sonuç: Deneysel çalışmalar F. tularensis'in Acanthamoeba spp. içerisinde hayatta kalabileceğini ve yaşamını sürdürebileceğini göstermesine rağmen çalışmamızda tularemi salgınları ve Acanthamoeba spp. arasında bir ilişki saptanmadı. Bu alanda yapılacak yeni araştırmalar tularemia epidemiyolojisine katkı yapabilir.

Anahtar Kelimeler: Francisella tularensis; Acanthamoeba; Tularemi; Çeşme suyu; PCR

\section{INTRODUCTION}

Francisella tularensis is a gram-negative, coccobacillus bacteria found in the northern hemisphere, causing tularemia disease. F. tularensis is transmitted by the inhalation of infective aerosols, the consumption of contaminated water and foods, being in contact with infectious fluid and animal tissues, and the bite of ticks and some flies. F. tularensis subsp. tularensis is transmitted to the humans by tick and mosquito, and it is found in Northern America. F. tularensis subsp. holarctica is found in Europe and Asia, and it is responsible for waterborne diseases ${ }^{[1,2]}$.

Tularemia disease has two different cycles, namely terrestrial cycle and water cycle. The main vectors of the terrestrial cycle are wild rabbits, ticks and certain fly species; whereas, beaver, muskrat, and other rat species play a role in the water cycle. The agent of the terrestrial cycle is $F$. tularensis subsp. tularensis, whereas, the agent of the water cycle is $F$. tularensis subsp. holarctica $^{[3,4]}$. F. tularensis subsp. holarctica is primarily isolated in Northern Europe, the Balkans, Turkey, Siberia, and the Far East, and it is mostly responsible for waterborne outbreaks ${ }^{[5]}$.

Even though the most common infection route in the world are contact with infected animal and tick, the consumption of non-chlorinated drinking water or spring water constitutes the main mode of transmission in Turkey, except for some rare cases transmitted by bovine saliva or tick borne $e^{[6,7]}$. The agent of tularemia outbreaks in Turkey is F. tularensis subsp. holarctica. It is known that the outbreaks are waterborne and it is acknowledged that water resources have been contaminated by rodents ${ }^{[8]}$.

More than 100 wild and domesticated mammal species, 25 bird species and some types of reptiles, ticks, and flies are accepted as reservoir for tularemia. Despite all of this 
information, there is not enough knowledge about the principal reservoir of $F$. tularensis. It is stated that amoebae of the genus Acanthamoeba can host the bacteria that are tularemia agents ${ }^{[1,5]}$.

In nature, there are various amoeba genus and species living freely in the environment such as soil, air and water. Among these amoebas, which are defined as voluntary or opportunistic pathogens, the ones that cause infection in humans belong to the Acanthamoeba, Naegleria, Balamuthia, Vahlkampfia and Sappinia genus ${ }^{[9,10]}$. In nature, free-living amoebas of the genus Acanthamoeba are isolated from various environments, they are commonly present in natural waters. Two phases can be distinguished in the life cycle of amoebae of the genus Acanthamoeba. The first phase is trophozoite form, where they are actively feeding, growing, multiplying and moving, whereas the second phase is the cyst form, where they are more resistant to external environmental conditions ${ }^{[9,10]}$.

Free-living amoebas feed by taking bacteria, algae and fungus found in the environment into the cell through phagocytosis. Numerous microorganisms having the habit of intracellular life may survive and multiply inside the amoebas through different mechanisms ${ }^{[11]}$. F. tularensis, which is a facultative intracellular bacterium, may survive inside Acanthamoeba castellani, which is a free-living amoeba in water resources; this symbiotic life allows the bacteria to survive in water and mud for months. It has been shown that $F$. tularensis can survive and multiply in the vacuole inside of trophozoite, in vesicles released out and in cysts ${ }^{[1-13]}$.

In case of producing the culture of $F$. tularensis and $A$. castellani together, intracellular bacteria can keep their vitality for more than three weeks. In case of cultivating $F$. tularensis alone, there is no living bacteria left in the environment after two weeks ${ }^{[13]}$. It is known that different genus of $F$. tularensis are taken inside $A$. castellani at different rates and they are multiplied inside the amoeba. In addition, it has been observed that there were bacteria in intracellular vesicles of amoeba 30 minutes after the infection of $A$. castellani by the pathogen $F$. tularensis. It is reported that live bacteria can be obtained from A. castellani cysts after 21 days. It is suggested that amoebae of the genus Acanthamoeba may be a significant environmental reservoir for $F$. tularensis ${ }^{[13,14]}$.

This study aimed to compare drinking water samples taken from tularemia outbreak and non-outbreak regions in the province of Sivas, in terms of the presence of $F$. tularensis and Acanthamoeba spp. and investigate the role of amoebae of the genus Acanthamoeba in tularemia outbreaks observed in Turkey.

\section{MATERIALS and METHODS}

This study was conducted in Sivas, which is a city located in the Central Anatolia region of Turkey. Three hundred samples of drinking water, collected between June 2011 and March 2012, were used in the study (Figure 1). Two hundred water samples were collected from 29 settlements, where tularemia outbreak had been observed (according to the information received from Sivas Provincial Directorate of Health). Water samples of 100 villages, where tularemia disease had not been observed, were selected from the water samples sent to Sivas Public Health Laboratory for periodic analysis (Table 1,2). Water samples were put in 2-liter plastic bottles and delivered to the laboratory in cold chain.

Water samples were filtered through $0.22 \mu \mathrm{m}$ pore diameter cellulose acetate membrane filters and after the filtration the filters were cut into two, by using a sterile scalpel. Half of the filter was placed on the antibiotic (Oxoid SR0147 and $150 \mathrm{U} / \mathrm{mL}$ Penicillin G) added Glucose Cysteine Blood Agar (GCBA) medium. The mediums were incubated at $37^{\circ} \mathrm{C}, 5 \% \mathrm{CO}_{2}$ for $4-10$ days. Agglutination test was carried out on the colonies formed on the filter with $F$. tularensis antiserum (BD Bioscience).

The other half of the filter was used on the isolation of DNA and Acanthamoeba spp. Filters were placed in $2 \mathrm{~mL}$ Eppendorf tubes containing water sample, kept one night at room temperature and vortexed for 5 minutes. $1 \mathrm{~mL}$ of water sample was taken and DNA isolation was carried out. For the isolation of Acanthamoeba spp., a water sample of $100 \mu \mathrm{L}$ was inoculated on $1.5 \%$ non-nutrient agar (NNA) plates containing Escherichia coli. Plates were incubated at $24^{\circ} \mathrm{C}$ and they 


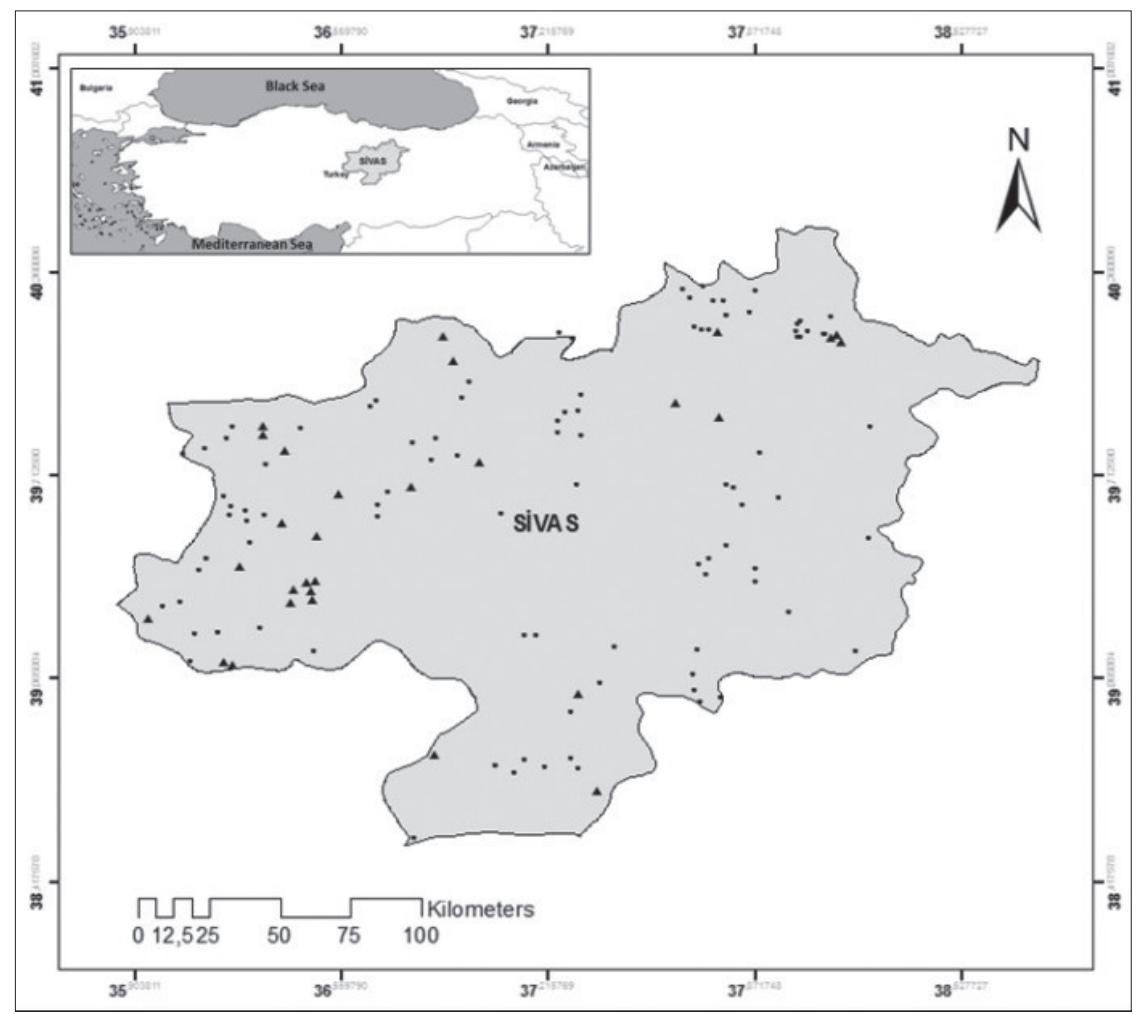

Figure 1. Geographical location of Sivas province and the distribution of the water samples used in the study (Triangles: outbreak regions, dots: non-outbreak regions).

Table 1. Distribution of examined water samples according to districts

\begin{tabular}{|c|c|c|c|c|c|c|c|c|c|c|c|c|}
\hline & 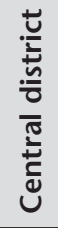 & 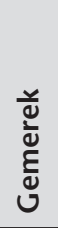 & : & $\begin{array}{l}\frac{\pi}{\frac{\pi}{n}} \\
\frac{\bar{x}}{\bar{N}} \\
\stackrel{n}{n}\end{array}$ & 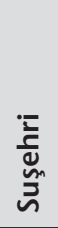 & $\begin{array}{l}\frac{\bar{y}}{\bar{N}} \\
\frac{\bar{v}}{\bar{x}}\end{array}$ & $\frac{\text { స్ }}{\text { N }}$ & $\begin{array}{l}\bar{\pi} \\
\text { O } \\
\frac{1}{\pi} \\
\underline{\Xi}\end{array}$ & 汤 & 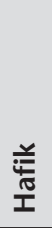 & 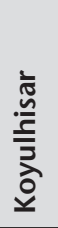 & $\begin{array}{l}\bar{\Xi} \\
0\end{array}$ \\
\hline Outbreak regions & 25 & 25 & 19 & 47 & 10 & 21 & 53 & --- & --- & --- & --- & 200 \\
\hline Non-outbreak regions & 10 & 9 & 9 & 9 & 9 & 9 & 9 & 9 & 9 & 9 & 9 & 100 \\
\hline Total & 35 & 34 & 28 & 56 & 19 & 30 & 62 & 9 & 9 & 9 & 9 & 300 \\
\hline
\end{tabular}

were observed through light microscope for 15 days. Amoebas of the genus Acanthamoeba were distinguished by their contractile vacuole, nucleus and typical cyst appearance.

DNA isolation was carried out for $F$. tularensis, Acanthamoeba spp. and the membrane filters using Commercial DNA isolation kit (QIAamp DNA extraction mini kit, Qiagen, Germany). Isolated DNAs were kept at $-20^{\circ} \mathrm{C}$, until $\mathrm{PCR}$ analysis.
TUL4 (Tul4-435 5'-GCT GTA TCA TCA TTT AAT AAA CTG CTG-3', Tul4-863 5'-TTG GGA AGC TTG TAT CAT GGC ACT-3') and RD1 (5'-TTT ATA TAG GTA AAT GTT TTA CCT GTA CCA-3', 5'-GCC GAG TTT GAT GCT GAA GA-3') primer base pairs were used for the detection of $F$. tularensis through PCR. As a result of the $\mathrm{PCR}$ performed with the primers belonging to Tul4 gene area, around 400 base farm areas were reproduced ${ }^{[15,16]}$. All PCR studies were performed using GeneAmp ${ }^{\circledR}$ PCR 
Table 2. Distribution of examined water samples according to the number of settlements

\begin{tabular}{|c|c|c|c|c|c|c|c|c|c|c|c|c|}
\hline & 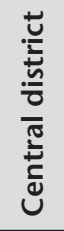 & 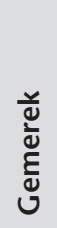 & :亏 & $\frac{\frac{\pi}{\omega n}}{\frac{\omega_{n}}{\frac{v}{\pi}}}$ & 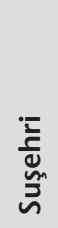 & $\begin{array}{l}\overline{\bar{N}} \\
\frac{N}{\overline{0}} \\
\bar{x}\end{array}$ & $\frac{\text { T⿱⺌兀 }}{N}$ & 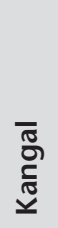 & 汤 & $\begin{array}{l}\text { 荡 } \\
\text { I }\end{array}$ & 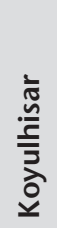 & 퓽 \\
\hline Outbreak regions & 3 & 3 & 3 & 9 & 3 & 5 & 3 & --- & --- & -- & --- & 29 \\
\hline Non-outbreak regions & 10 & 9 & 9 & 9 & 9 & 9 & 9 & 9 & 9 & 9 & 9 & 100 \\
\hline Total & 13 & 12 & 12 & 18 & 12 & 14 & 12 & 9 & 9 & 9 & 9 & 129 \\
\hline
\end{tabular}

System 9700 (Applied Biosystems, Foster City, CA) thermal cycle device.

The reaction volume of $50 \mu \mathrm{L}$ consisted of; 1x PCR buffer, $0.2 \mathrm{mM}$ dNTP, $2.5 \mathrm{mM} \mathrm{MgCl}_{2}$, $0.4 \mu \mathrm{M}$ primer, $1.25 \mathrm{U}$ Taq polymerase, and 5 $\mu \mathrm{L}$ DNA. The target DNA was denatured by keeping it for $4 \mathrm{~min}$, at $94^{\circ} \mathrm{C}$, and then a total of 40 cycles $\left(40 \mathrm{sec}\right.$ at $94^{\circ} \mathrm{C}, 30 \mathrm{sec}$ at $64^{\circ} \mathrm{C}$ and $45 \mathrm{sec}$ at $72^{\circ} \mathrm{C}$ ) were carried out. At the last stage, final elongation was realized by holding it $5 \mathrm{~min}$ at $64^{\circ} \mathrm{C}$ and the reaction was completed.

DNA isolation of the amoeba reproduced at NNA plates was also carried out. JDP1 (5'- GGC CCA GAT CGT TTA CCG TGA A-3') and JDP2 (5'- TCT CAC AAG CTG CTA GGG AGT CA3') primer base pair was used to identify amoebae of the genus Acanthamoeba through PCR (towards 18S rDNA gene area). Approximately an area of $500 \mathrm{bp}$ is reproduced in 18S rDNA gene region, among 423 to 551 base pairs ${ }^{[17]}$. The reaction volume of $50 \mu \mathrm{L}$ consisted of; $1 \mathrm{x}$ PCR buffer, $0.2 \mathrm{mM}$ dNTP, $2.5 \mathrm{mM} \mathrm{MgCl}_{2}, 0.4$ $\mu \mathrm{M}$ primer, $1.25 \mathrm{U}$ Taq polymerase, and $5 \mu \mathrm{L}$ DNA. The target DNA was denatured by keeping it for $7 \mathrm{~min}$ at $94^{\circ} \mathrm{C}$, and then a total of 40 cycles $\left(1 \mathrm{~min}\right.$ at $94^{\circ} \mathrm{C}, 1 \mathrm{~min}$ at $65^{\circ} \mathrm{C}$ and 1 $\min$ at $72^{\circ} \mathrm{C}$ ) were realized. At the last stage, final elongation was carried out by holding it 10 min at $72^{\circ} \mathrm{C}$ and the reaction was completed. The amplification products were evaluated after executing in agarose gel.

Data obtained from the study were analyzed using SPSS 20.0 (Statistical Package for the Social Sciences) software. Margin of error was set as $\alpha: 0.05$ and Chi-Square test was used to compare the results.

\section{RESULTS}

In this study, $F$. tularensis was reproduced in 30 water samples collected from 8 villages of 3 different districts where tularemia outbreak was observed (Table 3). Overall, F. tularensis was produced in 30 of the 200 water samples collected from outbreak areas (15.00\%); however, it could not be isolated from 100 water samples

Table 3. Settlements where $F$. tularensis was isolated

\begin{tabular}{lcc} 
County & Area & Sample Number \\
\hline Gemerek & Çiçekoğlu village & T131 \\
Gürün & Bahçeiçi village & T135 \\
Gürün & Karaören village & T173, T174, T175, T181, T182, T183 \\
Şarkışla & Hüyük village & $\mathrm{T} 142, \mathrm{~T} 144, \mathrm{~T} 145, \mathrm{~T} 146, \mathrm{~T} 148, \mathrm{~T} 149, \mathrm{~T} 151, \mathrm{~T} 152, \mathrm{~T} 153$, \\
& & $\mathrm{T} 163, \mathrm{~T} 164, \mathrm{~T} 165, \mathrm{~T} 166, \mathrm{~T} 167, \mathrm{~T} 168, \mathrm{~T} 169, \mathrm{~T} 170, \mathrm{~T} 171$ \\
Şarkışla & Maksutlu village & $\mathrm{T} 184$ \\
Şarkışla & Döllük village & $\mathrm{T} 186$ \\
Şarkışla & Belkent fountain & $\mathrm{T} 187$ \\
Şarkışla & Gazi village & $\mathrm{T} 198$
\end{tabular}


Table 4. Isolation results of $F$. tularensis and Acanthamoeba spp.

\begin{tabular}{|c|c|c|c|c|c|c|c|}
\hline & $\mathbf{n}$ & F. tularensis & $\%$ & Acanthamoeba spp. & $\%$ & $\begin{array}{c}\text { F. tularensis+ } \\
\text { Acanthamoeba spp. }\end{array}$ & $\%$ \\
\hline Outbreak regions & 200 & 30 & 15.00 & 16 & 8.00 & 2 & 1.00 \\
\hline Non-outbreak regions & 100 & 0 & 0.00 & 12 & 12.00 & 0 & 0.00 \\
\hline Total & 300 & 30 & 10.00 & 28 & 9.33 & 2 & 0.66 \\
\hline
\end{tabular}

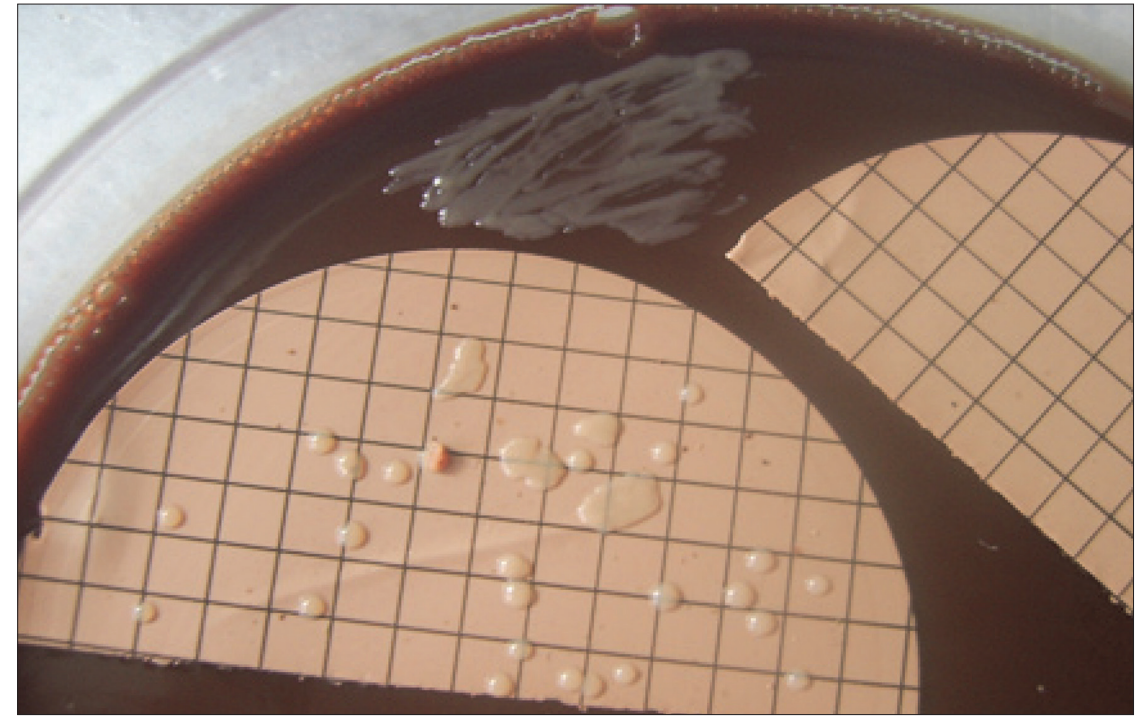

Figure 2. F. tularensis colonies on the GCBA.

collected from non-outbreak areas (Table 4). It was observed that 3-1000 F. tularensis colonies were formed on membrane filters (Figure 2). PCR analysis identified that the bacteria multiplied in the culture were $F$. tularensis subsp. holarctica.

Acanthamoeba spp. isolation occurred in 16 of the 200 water samples (8.00\%) collected from tularemia outbreak areas and 12 of the 100 water samples (12.00\%) collected from non-outbreak areas. Overall, Acanthamoeba spp. isolation occurred in 28 of the 300 water samples. Twenty-eight Acanthamoeba spp. isolates reproduced in culture environment were verified through PCR.
In our study, concurrent presence of amoebas of the genus $F$. tularensis and Acanthamoeba was only detected in two water samples (Table 4). There were no statistically significant differences between the water samples taken from outbreak and non-outbreak regions in terms of the presence of amoebae of the genus Acanthamoeba ( $p>$ 0.05) (Table 5). DNA isolation was carried out on the membrane filters and on 28 Acanthamoeba isolates, and they were examined in terms of the presence of $F$. tularensis DNA through PCR. At the end of the PCR carried out using genus specific Tul4 primers, the existence of $F$. tularensis DNA was not detected on membrane filters and on Acanthamoeba isolates.

Table 5. Isolation results of Acanthamoeba spp.

\begin{tabular}{lccccc} 
& $\mathbf{n}$ & Acanthamoeba spp. (+) & $\%$ & Acanthamoeba spp. (-) & $\%$ \\
\hline Outbreak regions & 200 & 16 & 8.00 & 184 & 92.00 \\
Non-outbreak regions & 100 & 12 & 12.00 & 88 & 88.00 \\
Total & 300 & 28 & 9.33 & 272 & 90.66
\end{tabular}




\section{DISCUSSION}

The first tularemia outbreak in Turkey was observed in 1936. Outbreaks increased after 2005, and waterborne outbreaks of tularemia have been reported from different regions of Turkey ever since. The agent of tularemia outbreaks emerged in Turkey is F. tularensis subsp. holarctica ${ }^{[18,19]}$. In diagnosing tularemia, culture is accepted as the golden standard, and $F$. tularensis was isolated from water samples via cultivation ${ }^{[5,20,21]}$. In Turkey, direct isolation of $F$. tularensis from water samples via cultivation was first realized in 2009 . The tularemia outbreak occurred in Sivas province during 2009-2010 was waterborne, and F. tularensis subsp. holarctica was detected in water samples through cultivation and PCR methods ${ }^{[22]}$. In our study, $F$. tularensis subsp. holarctica was isolated from water samples, which confirms that the outbreaks are waterborne.

The presence of $F$. tularensis subsp. holarctica in water is not sufficient for the emergence of the disease, the involvement of susceptible hosts is required for the disease ${ }^{[23]}$. In a study conducted in Sweden, F. tularensis subsp. holarctica has been detected in the water samples of the regions where tularemia disease was not present ${ }^{[23]}$. In our study, we could not detect the presence of $F$. tularensis subsp. holarctica through culture and PCR methods in the water samples of the regions where tularemia cases were not observed.

In our study, half of the membrane filters was used in cultivation work, whereas, the other half was used in DNA isolation. Although the formation of $F$. tularensis colonies (in the range of 3-1000 CFU) were observed on membrane filters during cultivation studies, the presence of bacteria DNA could not be detected in the same water samples through conventional PCR method. Real time detection limit of PCR was found to be $10^{3} \mathrm{CFU} / \mathrm{ml}$ for the DNA obtained from $F$. tularensis using commercial DNA isolation kits ${ }^{[24]}$. In addition, $10^{2}$ bacteria present in $1 \mathrm{ml}$ phosphate buffered water and $10^{3}$ to $10^{4}$ bacteria included in $1 \mathrm{ml}$ serum sample containing $F$. tularensis can be detected using conventional PCR method towards Tul4 gene area ${ }^{[25]}$. We believe that the small number of bacteria on membrane filters and the removal of bacteria from cellulose nit- rate filters has decreased DNA efficiency, which caused the negative results obtained from PCR analysis.

It is known that amoebae of the genus Acanthamoeba spp. are present in water resources such as drinking water, well water, spa water, rivers, and sea water at different rates ${ }^{[26-31]}$. Acanthamoeba spp. ratio found in the drinking water of Sivas province was $4.4 \%$ and $6.0 \%$ in two different studies; however, in our study this ratio was found to be $9.33 \%[32,33]$. This ratio was $8 \%$ for the samples taken from outbreak regions, whereas, it was $12 \%$ for the samples of non-outbreak regions.

F. tularensis is quite resistant to external environmental conditions, and it is accepted that its ability to sustain its life inside the amoebas living in water (Acanthamoeba castellani) is significant in terms of waterborne epidemics and regional continuity of the disease $e^{[11]}$. Experimental studies have reported that in case of cultivating $F$. tularensis and $A$. castellani together, the bacteria can keep its vitality for longer than three weeks ${ }^{[13,14]}$.

In our study, concurrent presence of $F$. tularensis and Acanthamoeba were detected in two water samples taken from Sarkıșla Hüyük village, numbered as T163 and T171. Although experimental studies show the complex relationship between F. tularensis and Acanthamoeba, the current study is first in terms of investigating F. tularensis and Acanthamoeba in water samples; however, no connection could be established between tularemia outbreaks and Acanthamoeba spp.

In conclusion, tularemia outbreaks emerged in Sivas province are waterborne and the agent is F. tularensis subsp. holarctica. Even though the bacteria were isolated from water samples through cultivation, the presence could not be detected through conventional PCR method. In case of low number of bacteria, it is more appropriate to use real time PCR method, which is more sensitive, instead of the conventional PCR method. Although experimental studies show the complex relationship between $F$. tularensis and Acanthamoeba, further studies investigating the role of Acanthamoeba in tularemia outbreaks are needed. 


\section{ACKNOWLEDGEMENT}

This work was supported by the Scientific Research Project Fund of Cumhuriyet University under the project number T-428. We would like to thank Dr. Can Bulent KARAKUS, for giving us technical support to present the samples used in our study on the map. The authors would like to thank the Sivas Cumhuriyet University Faculty of Medicine Research Center (CÜTFAM) for its technical support.

\section{ETHICS COMMITTEE APPROVAL}

Since the study was produced from a $\mathrm{PhD}$ thesis and pre-2020 data, the ethical approval for this study is not required.

\section{CONFLICT of INTEREST}

The authors declare that they have no conflict of interest.

\section{AUTHORSHIP CONTRIBUTIONS}

Concept and Design: MA, ÖP

Analysis/Interpretation: MA, ÖP

Data Acquisition: MA

Writing: MA

Revision and Correction: MA, ÖP

Final Approval: MA, ÖP

\section{REFERENCES}

1. Ellis J, Oyston PCF, Green M, Titbal RW. Tularemia. Clin Microbiol Rev 2002; 15: 631-46.

2. Tarnvik A, Berglund L. Tularemia. Eur Respir J 2003; 21: 361-73.

3. Mörner T. The ecology of tularemia. Rev Sci Tech 1992; 11: 1123-30.

4. Nigroviç LE, Wingerter SL. Tularemia. Infect Dis Clin North Am 2008; 22; 489-504.

5. World Health Organisation. WHO Guidelines on Tularemia. WHO/CDS/EPR/2007.7. Geneva WHO; 2007.

6. Bıçakcı Z, Öztürk B. Iki Yaşında Bir Çocuğa Sığır (inek) Salyasından Tularemi Bulaşımı: Uzun Erimli Izlemi ile Vaka Sunumu. Çocuk Dergisi 2008; 8: 197-9.

7. Yeşilyurt M, Kılıç S, Çağaşar Ö, Çelebi B, Gül S. Yozgat ilinde Kene Kaynaklı iki Tularemi Olgusu. Mikrobiyol Bul 2011; 45: 746-754.

8. Kilic S, Birdsell DN, Karagöz A, Çelebi B, Bakkaloglu Z, Arikan $M$, et al. Water as source of Francisella tularensis infection in humans, Turkey. Emerg Infect Dis 2015; 21: 2213-6.
9. Khan NA. Acanthamoeba: biology and increasing importance in human health. FEMS Microbiol Rev 2006; 30: 564-95.

10. Visvesvara GS, Moura H, Schuster FL. Pathogenic and opportunistic free-livingamoebae: Acanthamoeba spp., Balamuthia mandrillaris, Naegleria fowleri and Sappinia diploidea. FEMS Immunol Med Microbiol 2007; 50: 1-26.

11. Greub G, Raoult D. Microorganisms Resistant to Free-Living Amoebae. Clin Microbiol Rev 2004; 17: 413-33.

12. Kantardjiev T, Velinov T. Interaction between Protozoa and microorganisms of the Genus Francisella. Problems of Infectious Disease 1995; 22: 34-5.

13. Abd H, Johansson T, Golovliov I, Sandström G, Forsman M. Survival and growth of Francisella tularensis in Acanthamoeba castellanii. Appl Environ Microbiol 2003; 69: 600-606.

14. El-Etr SH, Margolis JJ, Monack D, Robison RA, Cohen M, Moore E, Rasley A. Francisella tularensis type A strains $\mathrm{Ca}$ use the rapid encystment of Acanthamoeba castellanii and survive in amoebal cysts for three weeks postinfection. Appl Environ Microbiol 2009; 75: 7488-500.

15. Sjöstedt, A, Eriksson U, Berglund L, Törnvik A. Detection of Francisella tularensis in Ulcers of Patients with Tularemia by PCR. J Clin Microbiol 1997; 35: 1045-8.

16. Broekhuijsen $M$, Larsson $P$, Johansson $A$, Byström $M$, Eriksson U, Larsson, E, Prior RG, Sjöstedt A, Titball RW, Forsman M. Genome-Wide DNA Microarray Analysis of Francisella tularensis Strains Demonstrates Extensive Genetic Conservation within the Species but Identifies Regions That Are Unique to the Highly Virulent F. tularensis subsp. tularensis. J Clin Microbiol 2003; 41: 2924-31.

17. Schroeder JM, Booton GC, Hay J, Niszl IA, Seal DV, Markus $M B$, Fuerst PA, Byers TJ. Use of subgenic 185 ribosomal DNA $P C R$ and sequencing for genus and genotype identification of acanthamoebae from humans with keratitis and from sewage sludge. I Clin Microbiol 2001; 39: 1903-11.

18. Gotschlich E, Berkin T. 1936 yılında Trakya'da Tülaremiye ait yapılan epidemiyolojik ve bakteriyolojik araştırmalar. Türk Hij Tec Biol Derg 1938; 1: 115-23.

19. KIlıç S. A General Overview of Francisella tularensis and the Epidemiology of Tularemia in Turkey. FLORA 2010; 15: 37 58.

20. Chitadze N, Kuchuloria T, Clark DV, Tsertsvadze E, Chokheli M, Tsertsvadze N, Trapaidze N, Lane A, Bakanidze L, Tsanava S, Hepburn MI, Imnadze P. Water-Borne Outbreak of Oropharyngeal and Glandular Tularemia in Georgia:Investigation and Follow-up. Infection 2009; 37: 514-21.

21. Kantardjiev T, Ivanov I, Velinov T, Padeshki P, Popov B, Nenova $R$, Mincheff M. Tularemia Outbreak Bulgaria 1997. 2005. Emerg Infect Dis 2006; 12: 678-80.

22. Simşek $H$, Taner $M$, Karadenizli $A$, Ertek $M$, Vahaboğlu $H$. Identification of Francisella tularensis by both culture and real-time TaqMan PCR methods from environmental water specimens in outbreak areas where tularemia cases were not previously reported. Eur J Clin Microbiol Infect Dis 2012; 31: 2353-7. 
23. Broman T, Thelaus I, Andersson AC, Bäckman S, Wikström P, Larsson E, Granberg M, Karlsson L, Bäck E, Eliasson H, Mattsson R, Sjöstedt A, Forsman M. Molecular Detection of Persistent Francisella tularensis Subspecies holarctica in Natural Waters. Int / Microbiol 201; 2011. http://dx.doi. org/10.1155/2011/851946

24. Dauphin LA, Walker RE, Petersen JM, Bowen MD. Comparative evaluation of automated and manual commercial DNA extraction methods for detection of Francisella tularensis DNA from suspensions and spiked swabs by real-time polymerase chain reaction. Diagn Microbiol Infect Dis 2011; 70: 299-306.

25. Grunow R, Splettstoesser W, McDonald S, Otterbein C, O'Brien T, Morgan C, Aldrich J, Hofer E, Finke EJ, Meyer $H$. Detection of Francisella tularensis in Biological Specimens Using a Capture Enzyme-Linked Immunosorbent Assay, an Immunochromatographic Handheld Assay, and a PCR. Clin Diagn Lab Immunol 2000; 7: 86-90.

26. Boost M, Cho P, Lai S, Sun WM. Detection of Acanthamoeba in Tap Water and Contact Lens Cases Using Polymerase Chain Reaction. Optom Vis Sci 2008; 85: 526-30.

27. Lorenzo-Morales J, Ortega-Rivas A, Foronda P, Martinez $E$, Valladares B. Isolation and identification of pathogenic Acanthamoeba strains in Tenerife, Canary Islands, Spain from water sources. Parasitol Res 2005; 95: 273-7.

28. leong HJ, Yu HS. The role of domestic tap water in Acanthamoeba contamination in contact lens storage cases in Korea. Korean J Parasitol 2005; 43: 47-50.

29. Winck MA, Caumo K, Rott MB. Prevalence of acanthamoeba from tap water in rio grande do Sul, Brazil. Curr Microbiol 2011; 63: 464-9.
30. Kao PM, Hsu BM, Chen NH, Huang KH, Huang CC, Ji DD, Chen JS, Lin WC, Huang SW, Chiu YC. Molecular detection and comparison of Acanthamoeba genotypes in different functions of watersheds in Taiwan. Environ Monit Assess 2012; 184: 4335-44.

31. Badirzadeh A, Niyyati M, Babaei Z, Amini H, Badirzadeh $H$, Rezaeian M. Isolation of Free-Living Amoebae from Sarein Hot Springs in Ardebil Province, Iran. Iranian J Parasitol 2011; 6: 1-8.

32. Özçelik S, Coşkun K, Yünlü Ö, Alim A. Potansiyel Patojen Serbest Yaşayan Amip Türlerinin Çevresel Su Kaynaklarından İzolasyonu Yaygınlığı ve Morfotiplendirmesi, 17. Ulusal Parazitoloji Kongresi ve Kafkasya ve Ortadoğu Paraziter Hastalıklar Sempozyumu Program ve Özet Kitabı, Kafkas Üniversitesi, 4-10 Eylül 2011; Kars, Türkiye.193.

33. Coșkun KA, Ozçelik S, Tutar L, Elaldı N, Tutar Y. Isolation and identification of free-living amoebae from tap water in Sivas, Turkey. Biomed Res Int 2013; 2013.http://dx.doi. org/10.1155/2013/675145

\section{Address for Correspondence/Yazıșma Adresi}

Dr. Öğr. Üyesi Mehmet ATAS

Sivas Cumhuriyet Üniversitesi Eczacllk Fakültesi, Farmasötik Mikrobiyoloji Anabilim Dalı,

Sivas-Türkiye

E-mail: atasmehmet@gmail.com 